\title{
William Shakespeare: Soliloquies and Asides in Hamlet
}

\author{
Farzana Nasrin \\ Assistant Professor \\ Department of English \\ Jessore University of Science and Technology \\ Jessore - 7408, Bangladesh \\ Md. Munibur Rahman \\ Assistant Professor, Department of English \\ Jessore University of Science and Technology \\ Jessore- 7408, Bangladesh
}

\author{
Md. Mehedi Hasan
}

Assistant Professor

Department of Language and Communication Patuakhali Science and Technology University Dumki, Patuakhali 8602, Bangladesh

\section{Mst. Kulsum Begum}

Associate Professor, Department of Basic

Science, Patuakhali Science and Technology

University, Dumki, Patuakhali 8602, Bangladesh

\author{
Dr. Md. Ati Ullah \\ Professor, Department of English \\ Shahjalal University of Science and Technology \\ Sylhet, Bangladesh
}

\begin{abstract}
In William Shakespeare's Hamlet, the tragic hero reveals his inner conflicts and introspective attitude in each of the lengthy soliloquies. Hamlet is a dynamic character whose thoughts have dramatically changed. Each soliloquy develops further into Hamlet's motivations, or lack of confidence and proof. Each soliloquy is united by vivid imagery, introspective language, and discussion of Hamlet's delay of action. The first soliloquy serves to 'set the stage' for the rest of Hamlet's thoughts, feelings and actions. Hamlet first reveals his hatred or his mother's incestuous marriage to his uncle Claudius, his low self-image and his great reverence for his father. The second soliloquy concerns Hamlet's delay of action. He feels ashamed that he has not avenged his father's death with speed and expression exhibited by the actors in the play. Hamlet compares his inaction to the dramatic expression the actor exhibits for the death of his father.Hamlet's soliloquies are foremost in bringing the idea of his delay o taking revenge. His soliloquies show that he is pre-occupied not only with thoughts of revenge but also with the problem of his procrastination and irresolution. Hamlet's soliloquies are influenced by plot. It is through the soliloquies that the intrinsic theme of Hamlet's procrastination is extended and realized. Without the soliloquies and asides, the play would be vacuous and sporadic, highly dramatic. They give it momentum, it forwards to new and exciting levels by influencing plot, characterization and mood, as well as expressing key themes. Hamlet's characteris filled out and further clarified through his soliloquies.Hence the interpretation of our hero very much depends on them. These intimate revelations permit to examine and discern Hamlet's true emotions. Hamlet's soliloquies are vital in establishing the mood and themes of the play. The soliloquies are triggered by self-doubt and distress at the corruption of Denmark. It explores the dimensions of the human character through Hamlet's sordid contemplation. The play becomes a dense examination of ho external difficulties affect man psychologically.
\end{abstract}

Keywords: soliloquies, introspective, aside, sordid.

\section{INTRODUCTION}

In Shakespeare's Hamlet, the tragic hero reveals his inner conflicts and introspective attitude in each of the lengthy soliloquies in the play. Each soliloquy develops further into Hamlet's motivations. Each soliloquy is united by vivid imagery, introspective language and discussion of Hamlet's delay of action. The asides in Hamlethave several different dramatic functions. Some of the asides are used to add a bit of irony to the play. There are as many as seven long soliloquies of Hamletin the play.The first of these occurs before he has seen the Ghost.The second soliloquy occurs just after the Ghost leaves him, after charging him with the duty of taking revenge upon the murderer of his father. Here Hamlet resolves to carry out the command of the Ghost. In the third soliloquy Hamlet accuses himself for his delay in executing the Ghost's revelation and seeks a confirmation of the Ghost against Claudius. Hamlet's fourth soliloquy is the most famous and philosophical of his soliloquies. The fifth 
soliloquy occurs when he is about to meet his mother. He describes his revenge motive like Nero, the Roman emperor. His sixth soliloquy occurs on his way to meet his mother in closet. This time the Ghost is visible to Hamlet and invisible to his mother. It seems to symbolizethe affinity between husband and wife. The Ghost here represents Hamlet's own conscience urging him to revenge and to some extent, scolding him for his inaction. Hamlet's last soliloquy is occasioned by his seeing young Fortinbras on his to invade Poland for very small plot of land.

\section{THE THEMES OF THE SOLILOQUIES}

In Hamlet's eyes Claudius is a beast in comparison to the God-like features of his father. This lays the foundation for Hamlet's vengeful intentions. Hamlet also comments on the loving relationship enjoyed by his parents, in disbelief of Gertrude's actions. He does not understand why his mother married Claudius in such haste, causing such internal torment for Hamlet. This leads Hamlet to make a generalization about all women. Frailty, thy name is woman! Hamlet displays his inability to separate his emotions from his rational being. Hamlet ends this soliloquy by resolving to do nothing for the time being. He has laid the foundation for the rest of the play, but he has also made a decision that will cause him more pain. His resolution to do nothing will be the source of his problems in following speeches.

The second soliloquy concerns Hamlet's delay of action. He feels ashamed that he has not avenged his father's death with the speed and expression exhibited by the actors in the play. Hamlet compares his inaction to the dramatic expression the actor exhibits for the death of his father. Hamlet is amazed that the actor can conjure such emotions without a real impetus, while he is incapable of doing anything in response to his father's murder. Hamlet then calls himself a coward for his inability to say anything in defense of his father. He is concentrating on the actor's expression of grief, not a proactive response, which will only inhibit one's action. Hamlet never discusses the act of vengeance, only the actor's ability to cleave the general ear with horrid speech. Hamlet also displays his low selfesteem in this soliloquy as he sarcastically describes his inaction.

He plans to put on a play that will mirror his father's murder in order to see Claudius's guilty reaction. Finally, Hamlet makes a plan. The third soliloquy shows Hamlet reverting back to the depressed mood of the first soliloquy. As soon as he made a plan of action, his thoughts regress. Hamlet's thoughts are about more than contemplation of suicide. He is questioning whether one should suffer the burdens of society or take action against it.

Hamlet would like to die only if he can enter a state of oblivion in which he would not be able to dream. The mystery of what comes after death is what keeps Hamlet from committing suicide. He says that people go through life with all of its problems because of dread of something after death. Hamlet's conscience is making him a coward by not allowing him to kill Claudius without knowing that he is justified without a doubt. Hamlet's pale cast of thoughts has continuously undermined his resolution, resulting in his inaction, which in turn causes him deep turmoil. This is the point in the play where Hamlet seems very noble. His inaction for which he considers himself a coward is revealed to be derived from a deeper source of morality and goodness.

\section{The DIFFERENCE BETWEen SOLILOQUY AND ASIDE}

A soliloquy is different from an aside. Though both in soliloquy and in aside only one character speaks, in aside some other characters remain present on the stage but in soliloquy none is allowed to be present on the stage. A soliloquy is also different from the dramatic monologue. The soliloquy is a dramatic technique but the dramatic monologue is a form of poetry in which a single speaker speaks to a silent listener who responds by physical gestures.

\section{The Soliloquy, A Dramatic Device}

The soliloquy is generally used as a means of revealing the inner working of the mind of a character. It is a device by employing which the dramatist can communicate to the audience or the readers the secret thoughts of a character while at the same time preserving the secrecy of those thoughts viv-a vis the other characters in the drama. By thus communicating to the audience or the readers the secret working of a character's mind, the dramatist throws additional light on the mental make-up of that character as also the mental progress or deterioration, if any, of that character. A soliloquy is thus a means of character revelation. Besides unfolding the inner life of the speaker, a soliloquy may also throw some light on another character by disclosing to us what the speaker thinks of that other 
character or those other characters. A soliloquy may contribute to the development of the plot by acquainting us with what the speaker proposes to do or decides to do. There are a number of soliloquies in Hamlet, most of these by the hero himself but a few by the villain.

\section{USE OF SOLILOQUY}

Shakespeare uses soliloquies and asides so that the audience may hear what the character is thinking, while the other characters on the stage do not. In Shakespeare's Hamlet, the tragic hero reveals his inner conflicts and introspective attitude in each of the lengthy soliloquies in the play. Each soliloquy is united by vivid imagery, introspective language and discussion of Hamlet's delay of action. The first soliloquy serves to 'set the stage' for the rest of Hamlet's thoughts, feelings and action. It is here that Hamlet first reveals his hatred for his mother's incestuous marriage to his uncle, his low selfimage and his great reverence for his father.

"O, that this too sallied flesh would melt,

Thaw, and resolve itself into a dew

Or that the Everlasting had not fixed

His canon against self-slaughter. O God, God,

How weary, stale, flat and unprofitable

Seem to me all the uses of this world!'(P.11)

Through these lines it is obvious that Hamlet is in the midst of a deep depression. He has no control over the uses of the world. Hamlet compares Denmark to an unwedded garden to symbolize the corruption within his country that is seeded withinClaudius and his incestuous marriage to Gertrude. Hamlet goes on to compare his father to Claudius and comment on the relationship between King Hamlet and Gertrude. So excellent a king that as to this Hyperion to a satyr so loving to my mother that he might not be teem the winds of heaven visit her face too roughly.

\section{HAMLET'S FirSt SOLILOQUY}

The first soliloquy of Hamlet occurs after the king and the Queen have urged Hamlet in the open court to cast off the deep melancholy whichhas taken possession of him as a consequence of his father's death. In this soliloquy, Hamlet reveals the grief that has been gnawing at his mind. He wishes that religion did not forbid suicide so that he could kill himself and be rid of this grief. Hamlet feels disillusioned with the world:

"Howweary, stale, flat, and unprofitable

Seem to me all the uses of this world!

Fie on't, ah, fie, 'tis an unwedded garden

That grows to seed. Things rank and gross in nature

Possess it merely. That it should come to this," (P.11)

He compares the world to an "unwedded garden" in which rank and gross things grow in great abundance. He deplores the fact that his mother has remarried a man much inferior to the husband she has lost. His mother should have so soon forgotten the husband who used to do it upon her whom she also loved fondly makes him believe that women are weak creatures. Even a beast would have mourned for a longer time. Hamlet considers this marriage of his mother to his uncle to be an incestuous affair. This soliloquy shows the meditative nature of Hamlet and prepares for the prolonged delay in his executing the command of the Ghost for revenge. This soliloquy shows the meditative nature of Hamlet and prepares for the prolonged delay in his executing the command of the Ghost for revenge. This soliloquy also throws some light on the character of Hamlet's dead father who was an excellent king and a loving husband. Hamlet's mother and his uncle fall in the estimation as a result of this soliloquy. The indecent haste of Hamlet's mother is getting remarried and her not observing even the ritual of mourning for a respectable period of time. This soliloquy also shows Hamlet's filial attachment to his dead father. Hamlet's reference to Hyperion, Niobe and Hercules show him to be ell-versed in classical literature. In this soliloquy, Hamlet's tendency is generalized. His first soliloquy reveals him to be thoroughly disgusted with Gertrude, Claudius and the world in 
general. He is saddened by the death of his father, who admired as a king and husband to his mother. His grief over his father's death is compounded by his mother's hasty marriage to Claudius.

\section{HAMLET'S SECOND SoliLOQUY}

Hamlet's second soliloquy comes after the Ghost leaves Hamlet, having charged him with the duty of taking revenge upon the murder of his father. Hamlet has been stunned by the revelation and echoes the Ghost's words asking him to remember it. Hamlet resolves to wipe out everything else from his memory and to preserve in it Ghost's "commandment" the manner in which Hamlet is speaking of never permitting himself to forget the Ghost's words. Hamlet will soon plunge into action and carry out the behest of the Ghost. He refers to his mother as a "most pernicious woman" and to his uncle as a "smiling damned villain". Hamlet's tendency is to generalization when he says:

"O most pernicious woman!

$\mathrm{O}$ villain, villain, smiling, damned villain!

My tables-meet it is I set it down

That one may smile, and smile, and be a villain.

At least I am sure it may be so in Denmark.” (p.23)

In his second soliloquy, Hamlet becomes curious and suspicious after hearing of the ghost. He said:

"My father's spirit in arms? All is not well:

I doubt some foul play. Would the night were come!

Till then sit still, my soul. Foul deeds will rise,

Though all the earth overwhelm them, to men's eyes."(p.14)

Hamlet feels the presence of the ghost indicates that his father died due to dubious circumstance. The question of his own death plagues Hamlet as well as he repeatedly contemplates whether or not suicide is a morally legitimate action in an unbearably painful world. Hamlet's grief and misery is such that he frequently longs for death to end his suffering, but he fears that if he commits suicide, he will be consigned to eternal suffering in hell because of the Christian religion's prohibition of suicide. In his famous soliloquy "To be or not to be" Hamlet philosophically concludes that no one would choose to endure the pain of life if he or she will come after death and that it is this fear which causes complex moral considerations to interfere with the capacity for action.

\section{The ThIRd SoliloquY}

Hamlet's third soliloquy occurs after he has a talk with Rosencrantz, Guildenstern and with the players. In this soliloquy Hamletbitterly scolds himself for his continuing failure to execute his revenge. The players shedding tears while reciting a speech descriptive of Hecuba's grief over the death of her husband stings Hamlet to the quick and makes him scold him for his inaction. Hecuba is nothing to the player, and yet the player wept over her fate.

He vents his anger upon his uncle by referring to him as a "a bloody, bawdy villain; remorseless, teachers, lecherous, kindles villain". (p.42,43) He then dwells upon his plan to stage a play by means of which he would be able to make sure whether or not his uncle is a murderer.

"Out of my weakness and my melancholy,

As he is very potent with such spirits,

Abuses me to damn me. I'll have grounds

More relative than this. The play's the thing

Wherein I'll catch the conscience of the king." (p.43)

This soliloquy clearly reveals Hamlet's incapacity for any vigorous kind of action, especially for premeditated bloody deed. It is hard to believe that Hamlet could not have found an opportunity for killing the king. If it were for a lack of opportunity that he has not acted so far, he would have mentioned the fact in this soliloquy. It is clear to use, as it is to him that has prevented him from doing anything is a natural want, or a natural deficiency. 
He realizes that it is his own lack of "gall to make oppression bitter" that has stood in the way of his own executing the command of the Ghost. If he had not been lacking in "gall", he should have "fatted all the region kites with this stave's offal", that is fed the kites with the flesh of the King. Hamlet condemns himself in round terms for his inaction and for merely indulging in words and curses "like a whore". This soliloquy thus makes it clear that are dealing with a philosopher, and not with a man of action. He now seeks a confirmation of the Ghost's charge against Claudius. This is rather strange; because it has taken him long to doubt the authenticity of the Ghost's charge. His entertaining a doubt regarding the truthfulness of the Ghost so long after the revelation was made by the Ghost seems merely a pretext for a further postponement of his duty of revenge. It now occurs to him that the Ghost which he has seen might have been the devil who appeared to him in the shape of his father and who wishes to exploit his weakness and melancholy. The players have come to Elsinore just by chance. We naturally ask what Hamlet would have done if the players had not come and thus provided him with the opportunity of seeking a confirmation of the Ghost's charge against Claudius.After talking with his father's ghost, in the third soliloquy Hamlet is angered by the news that Claudius had murdered his father. Hamlet assures that he will think of nothing but revenge.

\section{The FourTh SoliloQuY}

Hamlet's fourth soliloquyis the most famous and the most celebrated because it is the most philosophical of all. In this soliloquy there are mental debates. Hamlet finds himself on the horns of a dilemma:

"To be, or not to be, that is the question:

Whether 'tis nobler in the mind to suffer

The slings and arrows of outrageous fortune,

Or to take arms against a sea of troubles,

And by opposing end them. To die, to sleep-

No more; and by a sleep to say we end" (p.45)

He asks which of the two alternatives is nobler whether silently to suffer the cruelties of fate or to put up a fight against the misfortunes of life. It would be better perhaps to commit suicide if death were to mean a kind of total sleep and total unconsciousness. The reason that prevents a man from committing suicide is that he does not know what is in store for him after death. It is the fear of what may happen after death that makes endure the ills and injustices of life. It is for this reason that a man's resolution or power of determination is weakened and a man finds himself unable to execute great enterprises. This soliloquy reveals the speculative temperament of Hamlet, his irresolute and wavering mind and his incapacity for any premeditated action of a momentous nature. This soliloquy also shows Hamlet's generalizing habit of thought. The lines in which he gives a catalogue of the misfortunes of life are a neat summing-up of the painful features of human existence the oppressor's wrong, the proud man's contumely, the pangs of disprized love, the laws delays, the insolence of office etc. The whole of this soliloquy has a universal appeal because Hamlet is speaking for all human beings. There are occasions in every man's life when he feels a strong desire to put an end to his life but is prevented from doing so by several considerations including those specifically mentioned by Hamlet. The dramatic purpose of this soliloquy is partly to explain Hamlet's delay in carrying out his purpose and to show at the same time the mental torture that Hamlet has been undergoing because of his failure to have carried out that purpose.

\section{Philosophical Interpretation of the Fourth SoliloquY}

Hamlet's soliloquies and asides express his melancholic nature. He commits himself to his father's charge above all, he distrusts others. He berates himself with guilt; he has a hard time stating a task, he analyzes philosophically and he seeks perfection. During the course of the play, Hamlet has six other extended monologues. It focuses on the way eleven different twentieth-century actors delivered Hamlet's soliloquies.

Hamlet's conscience is making him a coward by not allowing him to kill Claudius without knowing that he is justified without a doubt. Hamlet's past cast of thoughts has continuously undermined his resolution, resulting in his inaction which in turn causes him deep turmoil. This is the point in the play where Hamlet seems very noble. His inaction, for which he considers himself a coward, is revealed to 
be derived from a deeper source of morality and goodness. In the last soliloquy Hamlet concerns more on action. First Hamlet accuses himself of thinking too much, resulting with no action. He wishes to cast aside his bestial oblivion. Hamlet also reveals that he does not know why he has yet to take advantage of the opportunity he has to kill Claudius. The irony lies in that he continues to ponder why he has not done anything, as he concludes that he ponders too much. Hamlet relates to Fortinbras because of the similarities in their situations but envies him because of the drastically different approach he takes to honor his father. Hamlet refers to Fortinbras as a divine prince because he respects what Fortinbras is doing to honor his father. However Hamlet also exhibits self-loathing in the process. Rightly to be great is not to stir without great argument but greatly to find quarrel in a straw when honor's at stake.

\section{DRAMATIC INTERPRETATION OF THE FOURTH SOLILOQUY}

Dramatic soliloquies are generally understood to be spoken by a character that is alone on stage or seems to be speaking private thoughts aloud. Yet there are many instances of overheard soliloquies, in which the character may or may not be aware of other characters thatare nearbybut concealed from the speaker. Soliloquies are often viewed as a dramatist's way of informing the theater audience about subtleties in the dramatic action or a character's motivation. However, critics invariably emphasize that evaluations of Shakespeare's soliloquies must take into account their dramatic context: while they may be viewed as a means of developing themes and characterization, they should not always be taken at face value-that is as forthright expressions of what the dramatist intended his audience to infer about the character speaking them. Maurice Charney asserts that most soliloquies and asides do not "provide a window into the souls of the characters". A major critical issue is whether soliloquies should be regarded as interior monologues or exterior addresses spoken to an on stage audience, if one exists, or to the theater audience. This is a crucial question for actors and directors.

In Hamlet's fourth soliloquies, his mental state shows signs of declination. He castigates himself for not taking action to avenge his father. He realizes that he has cause to kill Claudius, but cannot muster the chutzpah to go through with it. He said-

"Remorseless, treacherous, lecherous, kindles villain!

Why, what an ass am I! This is most brave,

That I, the son of a dear father murdered,

Prompted to my revenge by heaven and hell,

Must like a whore unpack my heart with words," (p.43)

He also expresses some doubt that the ghost was telling the truth.

\section{THE FIFTH SOLILOQUY}

Hamlet's fifth soliloquy occurs when he is about to go to his mother's chamber in response to her summons. Hamlet is at this moment in a mood in which he could-

"O heart, lose not thy nature; let not ever

The soul of Nero enters this firm bosom.

Let me be cruel, not unnatural;

I will speak daggers to her, but use none.

My tongue and soul in this be hypocrites:

How in my words some ever she be shent,

To give them seals never my soul consent!" (p.57)

He therefore decides to speak daggers to his mother, but use none. There is nothing remarkable in Hamlet's decision here because she has done nothing to deserve it apart from remarrying too soon. In fact it is strange that such a thought should at all arise in his mind. It does him no credit to think such a thought because although he has sufficient reason to hate and detest, he has no reason to kill her.

In the fifth soliloquy, Hamlet hits upon a mental nadir. As he contemplates suicide, Hamlet asks himself if it is more honorable to live with life's misfortunes or to die young and bypass all the 
hardships. Hamlet suggests that the reason of death, expect that it is final. It is "the undiscovered country from whose bourn no traveller returns". He goes on to say, "Thus conscience does make cowards of us all". Subscribing to this theory, Hamlet takes the cowards way and does not take his life.

\section{THE SIXTH SoliLOQUY}

Hamlet's next soliloquy shows him shrinking from an act for which he has so long been preparing and for which he now gets an excellent opportunity. Hamlet is prevented from killing the King at this stage by the thought that by killing the King is at his players, he would be sending him straight to heaven. Hamlet's father was murdered at a moment when there was no reason for God to extenuate his crimes and misdeeds, and Hamlet's father must accordingly be paying the divine penalty for those crimes and misdeeds. For Hamlet to kill the murderer of his father when that murderer is at players would be no revenge at all because the victim, being at this moment in direct communication with God, would be received in heaven. Hamlet therefore decides against killing the King at this moment. He tells himself that he will wait for an opportunity when the King is-

"When he is drunk asleep, or in his rage

Or in th' incestuous pleasure of his bed,

At game a-swearing, or about some act

That has no relish of salvation in't-

Then trip him, that his heels may kick at heaven," (p.60)

Although some people may endure the position that Hamlet adopts here, it is clear that Hamlet is merely evading the responsibility which has been entrusted to him and which on moral grounds, he has fully accepted. His reasoning that the King if killed at this moment would go straight to heaven is nothing but a piece of casuistry. In any case, this soliloquy further emphasizes Hamlet's dilatoriness and his tendency to procrastination. Hamlet's mental status shows some promise in his sixth soliloquy. Extremely resentful towards Gertrude, part of Hamlet really wants to hurt her. Sensibility prevails as he admits that it is not his nature to harm.

\section{HaMlet's LaSt SOLILOQUY}

Hamlet's last soliloquy occurs just after he has spoken to a Norwegian captain and learnt that young Fortinbrastroops are about to invade some part of Poland in order to acquire a small territory which Hath in it no profit but the name. The information has given to him by the captain stimulates his thought of revenge and makes him scold himself for his inaction.

"How all occasions do inform against me,

And spur my dull revenge! What is a man,

If his chief good and market of his time

Be but to sleep and feed? A beast, no more.

Sure he that made us with such large discourse," (p.71)

A man is no better than a beast if he is satisfied only with sleeping and feeding himself. God gave reason to human beings so that may make use of it. This is responsible for his procrastination. A man is justified in acting if his sense of honor demands that he should even "final quarrel in a straw". $\mathrm{He}$ had a powerful motive to act. Having reproached himself thus Hamlet forms the following resolve:

"The imminent death of twenty thousand men

That for fantasy and trick of fame

Go to their graves like beds, fight for a plot

Whereon the numbers cannot try the cause," (p.71)

This soliloquy again emphasizes Hamlet's irresolution and his reflective nature. His conscience keeps pricking him and urging him to his revenge but a natural deficiency in him always thwarts his purpose. His generalizing and universalizing tendency seen in his other soliloquies is the evident. In 
his seventh and final soliloquy Hamlet gains the courage to finally avenge his father. After talking with a captain in Fortinbras army Hamlet is inspired by the men going to Poland to fight for not much more than pride. Hamlet then feels ashamed of his unwillingness to go after Claudius. It dawned on Hamlet that he had been thinking too much and acting too little.

\section{The Cause of Delay in Taking Revenge}

Hamlet is finally alone and the stage is set for the soliloquy that gave rise to one of the most persistent mysteries in literature. Different authors have presented different reasons for the delay which in itself raises another question concerning this puzzling aspect of the play. First Shakespeare makes it clear that Hamlet is acutely aware of a delay. Second, Shakespeare also makes it clear that Hamlet himself is not sure why he delays. There is no need for Shakespeare to emphasize these two things unless he is making a point. The truth is that Hamlet himself had not brought it to our attention. Shakespeare stresses the point that Hamlet is delaying. Thus, it is meaningless to argue that Hamlet is not responsible for the delay hen Shakespeare clearly wants to see that he is.

In the nineteenth century, the romantics A. w. Schlegeand S. T. Coleridge offered the solution that Hamlet is rendered incapable of action because of his tendency to philosophize too much. Taking the cue from his own words, they proposed that Hamlet's "native hue of resolution is sicklied over with the pale cast of thought". According to Coleridge, Hamlet had "great enormous, intellectual activity, and a consequent proportionate aversion to real action". Coleridge concluded that "Shakespeare wished to empress upon the truth that action is the chief end of existence.

Shakespeare gives prominence to the delay because he wantsto emphasize that Hamlet's course of action is morally dubious. Shakespeare also does not try to conceal this meaning until the end. He actually took great pains to suggest it, right from the beginning of the play. He could not allow Hamlet to state it explicitly for a good reason. If Hamlet had recognized the cause of his delay, it would have altered the course of the action and defeated Shakespeare's main purpose in the play.

The soliloquies in Hamlet do not hold up the action of the play. They are in the fullest sense, dramatic part of the action. Shakespeare soliloquies in Hamlet differ radically from their common convention as essential speeches to argumentative understanding. On the contrary, they are just as important as the segments where character interaction occurs. Without the soliloquies, the play would be vacuous and sporadic. Highly dramatic, they give it momentum; propel it forward to new and exciting levels by influencing plot, characterization and mood are expressing the key themes. This is primarily basedon the fact that much of Hamlet involves a struggle with the self. There are conflicts between characters but there are also individual existence and psychological conflicts.Hamlet's highly second and third soliloquies are two such arias. Hence in Hamlet, soliloquies should not be considered standalonespeeches as they are integral to play action.

\section{The EFfeCtS OF ASIDES IN HAMLET}

Asides unlike a soliloquy that is spoken when the speaker is the only actor on stage an aside is spoken by an actor when there are actors present on the stage. The aside is alsomeant for the audience but sometimes an aside is spoken to an actor on the stage but not to all of the actors on the stage. The asides in Hamlethave several different dramatic functions; some of the asides are used to add a bit of irony to the play. The asides have the function of helping to set the plot of the play. The first line said by Hamlet is an aside in which Hamlet tells his feelings on the King of Denmark. Hamlet and the King are not direct kin that is to say father and son but the King is married to his mother. He is only the nephew of Claudius but also in the position of a son within the marriage.

Hamlet is not on good terms with the King after the hasty marriage to his mother. It turns out to be ironic that Hamlet has chosen to tell the King turns out to be his 'arch-enemy'. His feelings towards the King are questionable and soon he will find out that the King is an enemy to the state of Denmark and the cause of why Hamlet is the state of mind that he is in. This aside will culminate with the story of the ghost to form the heaviest part of the plot of different subplots. The aside which is given by Plolonius is very ironic:

"Though this be madness, yet there is method in it-

Will you walk out of the air, my lord?" (p.34)

The Lord says this after saying that he thinks Hamlet is crazy. He realizes that possibly Hamlet is not crazy or still a little bit there. 
"How pregnant sometimes his replies are! A happiness that often madness hits on, which reason and sanity could not so prosperously be delivered of. I will leave him, and suddenly contrive the means of meeting between him and my daughter." (p.34)

Polonius is quick to negate the possibility of Hamlet even being a little bit there. It is the wit of Hamlet that keeps him alive to the end. By dismissing the smarts of Hamlet Polonius is setting his own doom and making the King and Queen See Hamlet how he thinks he is. By giving the King ignorant opinion he helps to alter the end of the play too. It is possible that the King would have taken more precautions had he thought that Hamlet was the least bit with it. One aside is used has a ironic function that serves as a premonition about the end of the final act of the play.

"Thy state is the more gracious, for "tis a vice to knowhim. He hath much land, and fertile. Let a beast be lord of beasts, and his crib shall stand at the King's mess. 'Tis a chough, but as I say, spacious in the possession of dirt". (p.93)

It is look at the deaths in the final scene. The calamity at the end arises out of the suspicions of the guilty and comes to an end with the death of Hamlet, the King, the Queen and Laertes. Do to the suspicions of the King and Laertes themselves Hamlet and the Queen will lose their lives. The ironic aspect of it is that Horatio is breathing these words tens of minutes or hours before the 'guilt spills itself'. Besides the use of dramatic irony with the asides the character of the actor is saying the aside. The audiences get a sort of psychological read of the character of the speaker.

Hamlet is responding to the play within the play. He is responding to a line said by the queen. The queen has just said how she would not remarry and Hamlet is saying that he does not believe that. This is a look at how Hamlet sees women in general. Do to what has occurred between him and Ophelia and how his mother has acted after the death of his father, he has a deep distrust of women. One promised him something and another he supposes promised his father something and they have both broken their words.

"Nay, then, I have an eye of you-If you love me, hold not off". (p.36)

Hamlet is contemplating the actions of his 'dear' friends from school, Guildenstern and Rosencrantz. $\mathrm{He}$ is assuming the purpose of the appearance of his two oldest friends. He knows their purpose on him for the King and Queen. His knowledge of this will again turn out to be significant later in the play. With this knowledge he escapes death by their hands and has them put to death. Polonius thinks that Hamlet is still in love with his daughter and in this he has another reason to spy or check-up on Hamlet. Polonius has already given his daughter the ultimatum concerning Hamlet. He is starting to think that Hamlet is a little crazy also. He also states that he thinks that Hamlet does not really know him.

"Still on my daughter". (p.38)

This aside is given shortly after the previous of Polonius's asides. The only thing has occurred since the previous one is that Hamlet has a talk with his two friends. This is showing the mentality of the Lord Chamberlain. He is stuck on the thought that Hamlet is in love with his daughter and is convinced to spy on Hamlet. He also faults to show respect for the intelligence of Hamlet which will have later effects. It shows that he is a man who thinks himself very smart and is not one who will change his mind easily. It also shows his parallel to Hamlet. They are both people who distrust those around them. Polonius goes to the extent of having people spy on his son in France.

Through the dramaticallyuse of asides in the play Hamlet the audience see many things. Through the few lines that are muttered here and there throughout the play in the form of asides the audiencesget a look inside of certain actors. There is also a bit of dramatic irony and premonitions. The largest contribution that these asides make to the play is that they help to form the plot of the play. Whether by giving the audiences look into the suspicious behavior of the actors which forms a major part of the plot or by setting the tension with Hamlet's first spoken words in the form of an aside.

\section{Conclusion}

Hamlet's soliloquies show that he is pre-occupied not only with thoughts of revenge but also with the problem of his procrastination and irresolution. Hamlet's irresolution and procrastination, Hamlet's madness, Hamlet's love for Ophelia- these are the main issues in the play. The soliloquies of Hamlet are among the weightiest in the whole range of Shakespearean drama. In Shakespeare's Hamlet the 
tragic hero reveals his inner conflicts and introspective attitude in each of the lengthy soliloquies in the play. Each soliloquy is united by vivid imagery, introspective language and discussion of Hamlet's delay of action. The first soliloquy reveals his hatred for his mother's incestuous marriage to his uncle, Claudius, his low self-image and his great reverence for his father. The asides inHamlet have several different dramatic functions. Some of the asides are used to add a bit of irony to the play, others are used to look into the character of the actor by what he says of others or what he says of himself and finally all of the asides have the function of helping to set the plot of the play. Thus the soliloquies serve the dramatic purpose of revealing the hero's character. These soliloquies deepen his tragic character by portraying him as a 'thinking' man. Without these soliloquies Hamlet would degenerate into a cheap melodrama.

\section{REFERENCES}

Alexander, Peter. Hamlet: Father and Son. Oxford: The Clarendon Press, 1955.

Bowers, Fredson. Elizabethan Revenge Tragedy.Princeton: Princeton University Press, 1940.

Bradley, A.C. Shakespearean Tragedy. $2^{\text {nd }}$ edition. New York: St. Martin's Press, 1978.

Campbell, Lilly B. Shakespeare's Tragic Heroes: Slaves of Passion. New York: Cambridge University Press, 1930.

Charney, M. Style in Hamlet. Princeton University Press, 1969.

Coleridge, S. T. Coleridge's Writings on Shakespeare, ed. T. Hawkes. New York: G. P. Putnam's Sons, 1959.

Eliot, T. S. Hamlet and His Problems, in Selected Essays. New York: Harcourt, Brace and World, 1950.

Fergusson, Francis. The Idea of a Theatre. Princeton: Princeton University Press, 1949.

Fisch, Harold. Hamlet and the world.New York: Thomas Y. Crowell, 1960.

Granville-Barker, Harley. Prefaces to Shakespeare.2 vols. Princeton: Princeton University Press, 1946-47.

Grebanier, B. The Heart of Hamlet. New York: Thomas Y. Crowell. 1960.

Harbage, Alfred. Shakespeare: A Reader's Guide. New York: Farrar, Straus and Co., 1963.

Jones, Ernest. Hamlet and Oedipus. New York: W. W. Norton, 1949.

Knight, G. W. The Wheel of Fire. Rev. ed. London: Metheun, 1949.

Knights, L. C. An Approach to Hamlet. London: Chatto and Windus, 1960.

Levin, Harry. The Question of Hamlet. Oxford: Oxford University Press, 1959.

Madariaga, Salvador de.On Hamlet. London: Hollis and Carter, 1948.

Ribner, Irving.Patterns in Shakespearean Tragedy.London: Methuen, 1960.

Rosen, William. Shakespeare and the Craft of Tragedy. Cambridge: Harvard University Press, 1960.

Sanders, Leonard.The Hamlet Warning.New York: Scribner, 1976.

Schucking, L. L. Character Problems in Shakespeare's Plays. New York: H. Holt, 1922.

Tillyard, E. M. W. Shakespeare's Problem Plays. London: Chatto and Windus, 1951.

Traversi, Derek. An Approach to Shakespeare.New York: Doubleday. 1956.

Walker, Roy.The Time Is Out of Joint.London: A. Dakers, 1948.

Wilson, J. Dover. What Happens in Hamlet. New York: Macmillan, 1940.

Dowden, Edward. Shakespeare: His Mind and Art.

Brooke, A. Stopford. Ten More Plays of Shakespeare.

Schucking, L. Levin. The Meaning of Hamlet.

Masefield, John. William Shakespeare.

Jump, John. Hamlet: A Selection of Critical Essays.

Muir, Kenneth. Hamlet.

Harbage, Alfred. Shakespeare: The Tragedies (A Collection of Critical Essays)

Bevington, David. Twentieth Century Interpretations of Hamlet. 
Furness, H. H. Hamlet (A New Variorum Edition)

Hubler, Edward. Hamlet (The Signet Classic Shakespeare)

Lott, Bernard. Hamlet (New Swan Shakespeare)

Stoll, E. E. Art and Artifice.

E. Prosser. Hamlet and Revenge.Stanford University Press, 1971.

Hylton, Jeremy. Shakespeare, William. The Complete Works of Shakespeare. 